\title{
Detection of serum amyloid-A concentration in the calf clinically diagnosed with pneumonia, enteritis and pneumoenteritis
}

\author{
A detecção de amilóide-A concentração sérica em bezerros com diagnóstico \\ clínico de pneumonia, enterite e pneumoenterites
}

\author{
Mustafa Kabu $^{I^{*}}$ Bulent Elitok $^{\mathrm{I}}$ Ismail Kucukkurt ${ }^{\mathrm{II}}$
}

\section{ABSTRACT}

The aim of this study is to determine serum amyloid- $A$ (SAA) concentration in the cases of pneumonia, pneumoenteritis, and enteritis which are frequently encountered in calves in veterinary medicine. Although a great deal of experimental studies has been conducted in this field, studies on naturally infected calves are quite few. Eighty calves at the age of 0-6 months were used in the study and the calves were divided into four groups. Due to the clinical examination, the calves diagnosed with pneumonia (Group P; $n=20$ ), with pneumoenteritis (Group PE; $n=20$ ) and with enteritis (Group E; $n=20)$ formed the disease group as the healthy ones formed the control (Group $C ; n=20)$ group. After the body temperatures of all calves were taken, blood samples were obtained from Jugular vein for haematological and biochemical measurements. As haematological, white blood cell (WBC), red blood cell (RBC), hemoglobin (Hb) and hematocrit (Hct) measurements were performed in Veterinary Hematology Analyzer. Serum amyloid-A (SAA), interleukin 1 (IL-1 $\beta)$, interleukin 6 (IL$6)$, tumor necrosis factor- $\alpha(T N F-\alpha)$ concentration measurements were carried out with ELISA reader by using commercial kits. Aspartate aminotransferase (AST), alanine aminotransferase $(A L T)$, albumin $(A L B)$, total bilirubin (T. Bil), total protein $(T P)$, gamma glutamyltransferase (GGT), blood urea nitrogen (BUN) concentration measurements were conducted in autoanalyzer by using commercial kits. In all disease groups ( $P, P E$, and $E)$ body temperature, haematologic parameters (WBC, RBC, $\mathrm{Hb}$ and Hct), serum biochemical parameters (AST, ALT, ALB, T. Bil, TP GGT and BUN), SAA concentration and serum concentrations of cytokines (IL-1 $\beta, I L-6$ and $T N F-\alpha)$ were determined to be higher in comparison to the control group $(P<0.005)$. According to these findings, routine measurement of serum SAA concentration in veterinary medicine is considered to be beneficial in determining the severity of the disease, in selecting the proper treatment, in monitoring the applied treatment, and detecting subclinical diseases. In the light of these findings we acknowledge that routine measurements of serum SAA concentration from the moment the calves are diagnosed with pneumonia, enteritis and pneumoenteritis in veterinary medicine until the actual cause is determined (bacteria, virus, parasites, etc.) would avail the clinician to, identify the severity of the disease, select the appropriate treatment and monitor the effectiveness of the treatment.

Key words: serum amyloid-A, calves, pneumonia, enteritis, pneumoenteritis.

\section{RESUMO}

Oobjetivo deste estudo é determinar amilóide A (SAA) da concentração sérica nos casos de pneumonia, pneumoenterites $e$ enterite, que são frequentemente encontrados em bezerros em medicina veterinária. Apesar de uma grande quantidade de estudos experimentais terem sido realizados neste campo, os estudos sobre animais com infecção natural são muito poucos. 80 vitelos com a idade de 0-6 meses de idade foram utilizados no estudo e os animais foram divididos em quatro grupos. Devido ao exame clínico, os bezerros diagnosticados com pneumonia (Grupo $P ; n=20$ ), com pneumoenterites (Grupo PE; $n=20)$ e com enterite (Grupo $E ; n=20)$ formaram o grupo de doença, como as saudáveis, formando o grupo controle (Grupo $C ; n=20)$. Após as temperaturas corporais de todos os bezerros, foram tomadas amostras de sangue que foram obtidas de veia jugular para medições hematológicas e bioquímicas. Como hematológica, glóbulos brancos (WBC), glóbulos vermelhos (RBC), hemoglobina $(\mathrm{Hb})$ e hematócrito (HCT) foram realizados em Hematologia Veterinária Analyzer. O soro amilóide-A (SAA), a interleucina 1 (IL-1 $\beta)$, interleucina $6(I L-6)$, fator de necrose tumoral (TNF- $\alpha$ ) medidas de concentração foram efectuadas com um leitor de ELISA, utilizando kits comerciais. Aspartato aminotransferase (AST), alanina aminotransferase $(A L T)$, albumina $(A L B)$, bilirrubina total $(T$. Bil), proteina total (TP), gama glutamiltransferase (GGT), ureia (BUN) às medições das concentrações foram realizadas em auto-analisador por utilizandos kits comerciais. Em todos os grupos de doenças (P, PE,

IDepartment of Internal Medicine, Faculty of Veterinary Medicine, Afyon Kocatepe University, ANS Campus, 03200, Afyonkarahisar, Turkey. E-mail: mkabu@aku.edu.tr. "Corresponding author.

IIDepartment of Biochemistry, Faculty of Veterinary, Afyon Kocatepe University, Afyonkarahisar, Turkey. 
e E), a temperatura corporal, parâmetros hematológicos (WBC, $R B C, H b$ e Hct), parâmetros bioquímicos de soro (AST, ALT, ALB, T. Bil, TP, GGT e BUN), a concentração $S A A$ e as concentrações séricas de citocinas (IL-1 $\beta$, IL-6 e TNF- $\alpha$ ) foram determinadas a ser mais elevadas em comparação com o grupo controle $(P<0,005)$. De acordo com estas descobertas, a medição rotineira da concentração de soro SAA em medicina veterinária é considerada benéfica para determinar a gravidade da doença, na selecção de um tratamento adequado, no seguimento do tratamento aplicado e para a detecção de doenças subclínicas. À luz desses resultados, reconhecemos que as medições de rotina da concentração $S A A$ soro do momento em que os bezerros são diagnosticadas com pneumonia, enterite e pneumoenterites em medicina veterinária, até que a causa real seja determinada (bactérias, virus, parasitas, etc.), seria aproveitar o clínico, a fim de identificar a gravidade da doença, além de seleccionar o tratamento adequado e monitorar a eficácia do tratamento.

Palavras-chave: soro-amiloide A, bezerros, pneumonia, enterite, enterite pneumo.

\section{INTRODUCTION}

In veterinary medicine, pneumonia, enteritis and pneumoenteritis cases comprise a large part of the diseases in calves. The large frequency in the occurrence of these calfhood diseases causes substantial impacts on several commercial dairy activities. As well as the costly treatment procedures of sick calves, the financial losses may include increased mortality, reduced growth, and increased age and difficulty at first calving (STANTON et al., 2012; WINDEYER et al., 2014). Some previously conducted studies indicated over all calfhood morbidity at the rates of $35 \%$ (WALTNER-TOEWS et al., 1986) with precise risks of neonatal calf diarrhea (NCD) and bovine respiratory disease (BRD) of 29 and $39 \%$, respectively (VAN DONKERSGOED et al., 1993; DONOVAN et al., 1998). The risk of mortality during the very first year of life ranged from 2.1 to $14 \%$ on grounds of the year, population and age of calves (WALTNER-TOEWS et al., 1986; GULLIKSEN et al., 2009). Diarrhea and BRD were considered to be involved in reduced weight gain (VIRTALA et al., 1996).

It has been reported that even though serum amyloid-A (SAA) level is quite low in healthy calves, the concentration can go up to about ten times in the event of inflammation; and therefore it can be regarded as an acute phase protein which is highly sensible to inflammation (PETERSEN et al., 2004). Several studies reported that SAA increased in the events of bacterial infections (HORADAGODA et al., 1993) and viral infections (ECKERSALL \& BELL, 2010; CECILIANI et al., 2012). Some studies by some researchers indicated that the diversity in SAA concentrations was a significant marker in detecting and monitoring acute, subacute and chronic infections (GRUYS et al., 1994; PETERSEN et al., 2004).

Proinflammatory cytokines such as interleukin-6 (IL-6), tumor necrosis factor (TNF- $\alpha$ ) and IL- $1 \beta$ are basic mediators of AFPs synthesized by the liver. While IL-6 is more efficient in the hepatic acute phase response, IL- $1 \beta$ and TNF- $\alpha$ are efficient in extra hepatic cases. These cytokines are mainly produced by macrophages; yet, in case of internal or external stimuli they might be produced by the other cells. IL- $1 \beta$ is produced by activated monocytes and macrophages. TNF is a polypeptide produced by macrophages which are stimulated by the lipopolysaccaride (MURATA et al., 2004).

New markers are needed in veterinary medicine for clinical diagnosis of the diseases and monitoring of prognosis. Previous studies on SAA are mostly experimental. However, the present study is about the clinical use of SAA in naturally infected calves. For this purpose, pneumonia, enteritis and pneumoenteritis cases which are frequently observed in neonatal calves were used. With the occurrence of clinical symptoms, SAA concentration was determined.

\section{MATERIAL AND METHODS}

In the study 80 calves at the ages of 0-6 months were used and they were divided into four groups. A thorough clinical examination was conducted in which respiratory rate were determined, rectal temperature was measured and a description of respiratory sounds and appearance and amount of nasal discharge were recorded. Coughing was noted during the clinical examination, and calves were examined for diarrhea; and haematological examinations were done. Healthy calves whose clinical examinations proved no pathological findings and haematological data were normal, therefore formed the Control group (Group $C ; n=20$ ). On the basis of clinical examination, the calves diagnosed with abnormal sound in lung auscultation, dyspnea, cough, nasal discharge, anorexia, depression, hyper salivation, lacrimation and accessible mucosal surface lesions were selected for pneumonia group (Group P, $\mathrm{n}=20$ ); the ones diagnosed with anorexia, depression, accessible mucosal surface lesions and diarrhea formed enteritis group (Group $\mathrm{E}, \mathrm{n}=20$ ) as the calves with lung auscultation, dyspnoea, cough, nasal discharge, anorexia, depression, hyper salivation, lacrimation, accessible mucosal surface lesions and 
diarrhea were chosen for the Pneumoenteritis group (Group PE, $\mathrm{n}=20$ ). From all calves in all groups, blood samples from jugular vein were collected in dry biochemistry tube for serum, and in tubes containing EDTA for plasma and haematological measurements.

With blood samples collected in EDTA containing tubes, measurements for leukocytes (WBC), red blood cell (RBC), hemoglobin $(\mathrm{Hb})$ and hematocrit (Hct) concentrations were performed in 9/5 Veterinary Hematology Analyzer (Modern Laboratory Services, Inc). Blood samples obtained for biochemical parameters and without anticoagulant were centrifuged at 5000rpm and room temperature. Serum was stored at $-20^{\circ} \mathrm{C}$ until the time of measurement. On the serum obtained from the blood collected, aspartate aminotransferase (AST), alanine aminotransferase (ALT), albumin (ALB), total bilirubin (T.bil), totalprotein (TP), gamma glutamyltransferase (GGT), blood urea nitrogen (BUN) concentration measurements were performed in autoanalyser (Roche Cobas C111 Germany) by using the Roche Diagnostics Germany commercial kit. On the serum obtained from blood sample; SAA (Tridelta Development LTD, Ireland) (ALSEMGEEST et al.1994), interleukin 1(IL-1 $\beta$ ), interleukin 6 (IL-6) and tumor necrosis factor- $\alpha$ (TNF- $\alpha$ ) concentration measurements were measured using the Bovine Interleukin 1,6 and $\mathrm{TNF}-\alpha$ ELISA Kits (Cusabio Biotech CO.LTD, China) as recommended by the manufacturer.

Statistical analysis was performed by using the SPSS (Windows) program via the computer. Shapiro-Wilk test was applied on the data and a heterogeneous distribution was seen. Minding the number of the subjects in each group $(n=20)$ and the heterogeneous distribution; Kruskal-Wallis test was applied to determine whether there was a significant diversity among the $\mathrm{C}, \mathrm{P}, \mathrm{PE}$ and $\mathrm{E}$ groups in terms of measured parameters. Mann-Whitney $U$ test was used for pairwise comparison of the groups which showed difference. Significance level was set at $\mathrm{P}<0.05$. To avoid Type 1 alpha error, a Bonferronicorrected Mann-Whitney U test was used for pairwise comparisons. Values on the table were given as mean \pm standard error.

\section{RESULT}

The average body temperatures $\left({ }^{0} \mathrm{C}\right)$ of the calves in the presented study groups, in a statistically significant manner $(\mathrm{P}<0.0001)$, were detected as $38.12 \pm 0.12^{\circ} \mathrm{C}$ in the Control group (C), $40.21 \pm 0.13^{\circ} \mathrm{C}$ in Pneumonia Group (P), $40.27 \pm 0.18^{\circ} \mathrm{C}$ in enteritis group (E), and $40.14 \pm 0.14^{\circ} \mathrm{C}$ in pneumoenteritis group (PE) (Table 1). As being statistically significant $(\mathrm{P}<0.0001)$, haematological findings for WBC $(\mu \mathrm{L})$, RBC (x10 $\left.\mu^{6} \mathrm{~L}^{-1}\right)$, Hemoglobin $(\mathrm{g} / \mathrm{dl})$ and Hematocrit (HCT/\%) concentrations were determined to be higher in $\mathrm{P}, \mathrm{PE}$ and $\mathrm{E}$ groups than in the group C. Highest concentrations were noted for WBC $(\mu \mathrm{L})$ in group E $(16187 \pm 81,04)$, for RBC $\left(10^{6} \mu \mathrm{L}^{-1}\right)$ in group $\mathrm{PE}$ $(9,720 \pm 0,29)$, for HB $\left(\mathrm{g} \mathrm{dl}^{-1}\right)$ in group $\mathrm{P}(14,81 \pm 1,43)$, and for HCT $(\%)$ in group E $(46,93 \pm 0,51)$ (Table 1).

Regarding the biochemical findings; serum aspartate aminotransferase (AST,U/L), alanine aminotransferase (ALT, $\mathrm{U} \mathrm{L} \mathrm{L}^{-1}$ ), albumin (ALB $\mathrm{g} \mathrm{dl}^{-1}$ ), total bilirubin ( $\mathrm{T}$. Bil, $\mathrm{mg} \mathrm{dl}^{-1}$ ), gamma glutamyltransferase (GGT, $\mathrm{U} \mathrm{L}^{-1}$ ), blood urea nitrogen (BUN, mg dl-1 $)$ concentrations in $\mathrm{P}, \mathrm{PE}$ and $\mathrm{E}$ groups were determined to be higher than Group $\mathrm{C}(\mathrm{P}<0.05)$ while Total Protein $(\mathrm{TP})$ concentration was higher in the group $\mathrm{C}$ than in the other groups. AST concentration was determined to be the highest in group P (78.33 \pm 7.90$)$; ALT, ALB and T.BİL concentrations were seen to be the highest in group PE $(23.95 \pm 8.33 ; 39.69 \pm 2.06 ; 0.20 \pm 0.03)$ while the highest GGT and BUN concentrations were detected in group E (37.86 $\pm 4.93 ; 30.94 \pm 1.95)$ (Table 2).

In our study, statistically significant $(\mathrm{P}<0.0001)$ variations were identified in Serum Amyloid-A (SAA, mg/L) concentration between the groups. Whereas the lowest SAA concentration was ascertained in group C (17.64 \pm 2.50$)$, the highest level was in group E (205.65 \pm 22.70$)$ (Table 3). As being statistically significant $(\mathrm{P}<0.0001)$, the lowest serum tumor necrosis factor- $\alpha$ (TNF- $\alpha)$ concentration was measured in group $\mathrm{C}(0.10 \pm 0.01)$ while the highest was in group $\mathrm{P}(0.31 \pm 0.03)$ (Table 3$)$. Statistically $(\mathrm{P}<0.0001)$, Serum Interleukin-1 $\beta$ (IL$1 \beta$ ) concentration was determined to be the lowest in group $\mathrm{C}(14.17 \pm 1.04)$ and the highest in group PE (57.26 \pm 4.40$)$ (Table 3). Serum Interleukin-6 (IL-6) concentration $(\mathrm{p}<0.0001)$ was identified as the lowest in group $\mathrm{C}(5.44 \pm 0.82)$ and as the highest in group $\mathrm{E}$ (22.14 \pm 2.82$)$ (Table 3).

\section{DISCUSSION}

In the presented study, mean body temperatures $\left({ }^{\circ} \mathrm{C}\right)$ were determined, as statistically significant $(\mathrm{P}<0.0001)$, the lowest in the control group (C) and the highest in enteritis group (E). As a conducted study reported that rectal body temperatures were about 39.0-39.23 in healthy calves (PICCIONE et al., 2010), another research emphasized that rectal body temperatures in calves 
Table 1 - In Control (C), Pneumonia (P), Pneumoenteritis (PE) and Enteritis (E) groups; Leukocyte (WBC $\left.\mu L^{-1}\right)$, Erythrocyte $\left(\mathrm{RBC}^{\mathrm{x}} \mathrm{x} 10^{6} \mu \mathrm{L}^{-1}\right), \mathrm{Hemoglobir}$ $\left(\mathrm{HB} \mathrm{g} \mathrm{dl}{ }^{-1}\right)$, Hematocrit $(\mathrm{HCT} / \%)$ concentrations and Mean Body Temperatures $\left({ }^{\circ} \mathrm{C}\right)$ (Mean $\left.\pm \operatorname{StdDev}\right)$.

\begin{tabular}{|c|c|c|c|c|c|}
\hline Parameters & $\mathrm{C}$ & $\mathrm{P}$ & PE & E & $\mathrm{P}$ \\
\hline WBC & $7275 \pm 27.90^{\mathrm{a}}$ & $16045 \pm 87.16^{\mathrm{b}, \mathrm{c}}$ & $13337 \pm 60.38^{b}$ & $16187 \pm 81.04^{\mathrm{c}}$ & $0.0001^{* *}$ \\
\hline $\mathrm{RBC}$ & $7.48 \pm 0.25^{\mathrm{ac}}$ & $8.75 \pm 0.23^{\mathrm{b}, \mathrm{d}}$ & $9.720 \pm 0.29^{b}$ & $8.33 \pm 0.30^{\mathrm{cdd}}$ & $0.0001^{* *}$ \\
\hline $\mathrm{HB}$ & $11.27 \pm 0.36^{\mathrm{a}}$ & $14.81 \pm 1.43^{\mathrm{b}}$ & $13.66 \pm 0.58^{\mathrm{b}}$ & $14.59 \pm 0.37^{\mathrm{b}}$ & $0.0001^{* *}$ \\
\hline HCT & $28.46 \pm 1.03^{\mathrm{a}}$ & $37.60 \pm 1.86^{\mathrm{b}}$ & $45.68 \pm 1.49^{c}$ & $46.93 \pm 0.51^{\mathrm{c}}$ & $0.0001^{* *}$ \\
\hline${ }^{0} \mathrm{C}$ & $38.12 \pm 0.12^{\mathrm{a}}$ & $40.21 \pm 0.13^{\mathrm{b}}$ & $40.14 \pm 0.14^{b}$ & $40.27 \pm 0.18^{b}$ & $0,0001^{* *}$ \\
\hline
\end{tabular}

${ }^{*} \mathrm{P}<0.05,{ }^{* *} \mathrm{P}<0.0001$. The variations between the groups were indicated with letters (a,b,c,d).

with diarrhea were elevated in relation to the severity of the infection and inflammation (RISALDE et al., 2011). Body temperature was reported to be elevated during bovine respiratory diseases in calves (GÜNEŞ et al., 2013). HANZLICEK et al. (2010) ascertained a rise in fever in the experimental pneumonia they created in calves. In the conducted study, body temperature was determined to be statistically $(\mathrm{P} \leq 0.05)$ higher in groups $\mathrm{P}, \mathrm{PE}$ and $\mathrm{E}$ than in the control group.

In our study, on haematological examination $\mathrm{WBC}, \mathrm{RBC}$, Hemoglobin and Hematocrit concentrations were determined, as statistically significant $(\mathrm{P}<0.0001)$, to be higher in groups $\mathrm{P}, \mathrm{PE}$ and $\mathrm{E}$ in comparison to group $\mathrm{C}$. WBC concentration was detected at reference ranges in the control $(7275 \pm 27.90)$ group. In the calves with experimental pneumonia, high $\mathrm{WBC}, \mathrm{RBC}$, Hct and $\mathrm{Hb}$ values were detected; those rises were reported to be related to infection (HANZLICEK et al., 2010). As those values were detected to be higher in group $\mathrm{P}$ than in the control group in our study as well, we suggest that this rise may be infection related. We detected highest WBC concentration in group E (16187 \pm 81.04$)$. Depending on the fact that
$\mathrm{RBC}, \mathrm{Hb}$ and Hct values were higher in groups $\mathrm{E}$ and $\mathrm{PE}$ than in the control group in our study, it was concluded that this situation could be associated to excessive fluid loss.

In groups $\mathrm{P}, \mathrm{PE}$ and $\mathrm{E}$; the concentrations of serum AST, ALT, ALB, T.Bil, GGT and BUN were statistically $(\mathrm{P}<0.05)$ higher than in group $\mathrm{C}$. Concentration of Serum TP was higher in group $\mathrm{C}$ than in the other groups. The highest concentrations detected were AST in group $\mathrm{P}(78,33 \pm 7,90)$, ALT, ALB and T.BİL in group PE $(23.95 \pm 8.33$; $39.69 \pm 2.06 ; 0.20 \pm 0.03)$, GGT and BUN in group E $(37.86 \pm 4.93 ; 30.94 \pm 1.95)$. In our study, although concentrations of serum AST, ALT, ALB, T. Bil, BUN were higher in $\mathrm{P}, \mathrm{PE}$ and $\mathrm{E}$ groups than in group $\mathrm{C}$, they remained at reference ranges (BRUNHANSEN et al., 2006; MERCK MANUAL, 2013). The concentration of GGT in group E presented above the reference ranges. We suggest that this resulted is related tothe negative impact of diarrhea on the gastrointestinal system and the liver.

Statistically significant $(\mathrm{P}<0.0001)$ variations between the groups were determined for the concentration of Serum Amyloid-A (SAA, mg $\left.\mathrm{L}^{-1}\right)$. The concentration of SAA was detected to be

Table 2 - In Control (C), Pneumonia (P), Pneumoenteritis (PE) and Enteritis (E) groups; AST (U L $\left.\left.{ }^{-1}\right), \operatorname{ALT}\left(\mathrm{U} \mathrm{L}^{-1}\right), \operatorname{ALB}\left(\mathrm{g} \mathrm{dl}^{-1}\right), \mathrm{T}_{\mathrm{BIL}}\left(\mathrm{mg} \mathrm{dl}{ }^{-1}\right), \mathrm{TP}^{(\mathrm{g} \mathrm{dl}}{ }^{-1}\right)$. GGT $\left(\mathrm{U} \mathrm{L}^{-1}\right)$ and BUN $\left(\mathrm{mg} \mathrm{dl}^{-1}\right)$ concentrations (Mean \pm StdDev).

\begin{tabular}{|c|c|c|c|c|c|}
\hline Parameters & $\mathrm{C}$ & $\mathrm{P}$ & PE & E & $\mathrm{P}$ \\
\hline AST & $58.13 \pm 2.85^{\mathrm{a}}$ & $78.33 \pm 7.90^{b}$ & $67.79 \pm 10.06^{\mathrm{a}, \mathrm{b}}$ & $65.23 \pm 7.83^{\mathrm{ab}}$ & $0.016^{*}$ \\
\hline ALT & $10.04 \pm 1.01^{\mathrm{a}}$ & $18.24 \pm 1.81^{\mathrm{b}}$ & $23.95 \pm 8.33^{\mathrm{b}, \mathrm{c}}$ & $12.54 \pm 1.61^{\mathrm{acc}}$ & $0.0001^{* *}$ \\
\hline ALB & $31.51 \pm 0.71^{\mathrm{a}}$ & $34.66 \pm 1.59^{\mathrm{a}, \mathrm{b}}$ & $39.69 \pm 2.06^{\mathrm{b}}$ & $39.14 \pm 1.33^{\mathrm{b}}$ & $0.001^{*}$ \\
\hline T.BİL & $0.10 \pm 0.00^{\mathrm{a}}$ & $0.17 \pm 0.02^{\mathrm{b}}$ & $0.20 \pm 0.03^{\mathrm{b}}$ & $0.16 \pm 0.02^{\mathrm{b}}$ & $0.004^{*}$ \\
\hline $\mathrm{TP}$ & $66.33 \pm 1.55^{\mathrm{a}}$ & $53.39 \pm 2.39^{\mathrm{b}}$ & $52.52 \pm 3.29^{b}$ & $54.17 \pm 2.06^{\mathrm{b}}$ & $0.0001^{* *}$ \\
\hline GGT & $14.57 \pm 1.05^{\mathrm{a}}$ & $24.28 \pm 2.86^{\mathrm{ac}}$ & $23.98 \pm 5.01^{\mathrm{a}}$ & $37.86 \pm 4.93^{\mathrm{b}, \mathrm{c}}$ & $0,0001^{* *}$ \\
\hline BUN & $18.55 \pm 0.69^{\mathrm{a}}$ & $27.14 \pm 2,26^{\mathrm{b}}$ & $28.81 \pm 2.74^{\mathrm{b}}$ & $30.94 \pm 1.95^{\mathrm{b}}$ & $0.0001^{* *}$ \\
\hline
\end{tabular}

${ }^{*} \mathrm{P}<0.05,{ }^{* *} \mathrm{P}<0.0001$. The variations between the groups were indicated with letters (a,b,c,d). 
Table 3 - In Control (C), Pneumonia (P), Pneumoenteritis (PE) and Enteritis (E) groups; SAA (mg L $\left.{ }^{-1}\right)$, TNF- $\alpha\left(n g \mathrm{ml}^{-1}\right), \mathrm{IL}^{-1}\left(\mathrm{pg} \mathrm{m} \mathrm{l}^{-1}\right)$ and IL-6 (pg ml $\left.{ }^{-1}\right)$ concentrations (Mean \pm StdDev).

\begin{tabular}{|c|c|c|c|c|c|}
\hline Parameters & $\mathrm{C}$ & $\mathrm{P}$ & $\mathrm{PE}$ & E & $P$ \\
\hline SAA & $17.64 \pm 2.50^{\mathrm{a}}$ & $112.19 \pm 10.55^{\mathrm{b}}$ & $136.89 \pm 16.35^{\mathrm{bcc}}$ & $205.65 \pm 22.70^{c}$ & $0.0001^{* * *}$ \\
\hline TNF- $\alpha$ & $0.10 \pm 0.01^{\mathrm{a}}$ & $0.31 \pm 0.03^{b}$ & $0.28 \pm 0.02^{\mathrm{b}}$ & $0.29 \pm 0.05^{\mathrm{b}}$ & $0.0001^{* *}$ \\
\hline IL-1 $\beta$ & $14.17 \pm 1.04^{\mathrm{a}}$ & $40.83 \pm 3.75^{\mathrm{b}}$ & $57.26 \pm 4.40^{\mathrm{b}}$ & $55.60 \pm 7.91^{\mathrm{b}}$ & $0.0001^{* *}$ \\
\hline IL-6 & $5.44 \pm 0.82^{\mathrm{a}}$ & $12.01 \pm 1.18^{\mathrm{b}}$ & $16.40 \pm 0.90^{\mathrm{c}}$ & $22.14 \pm 2.82^{\mathrm{c}}$ & $0.0001^{* *}$ \\
\hline
\end{tabular}

${ }^{*} \mathrm{P}<0.05,{ }^{* *} \mathrm{P}<0.0001$. The variations between the groups were indicated with letters $(\mathrm{a}, \mathrm{b}, \mathrm{c}, \mathrm{d})$.

the lowest in group $\mathrm{C}(17.64 \pm 2.50)$ as it was the highest in group E $(205.65 \pm 22.70)$. It was reported that in calves which experimentally pneumonia was created via bovin respiratory syncytial virus (BRSV), the concentration of SAA increased between the day 4 and 8 together with pathological sounds detected in lung auscultation (HEEGAARD et al., 2000). On the other hand, some studies noted that the concentrations of SAA and haptoglobin remained at normal ranges during experimentally created bacterial and aseptic infections (ALSEMGEEST et al., 1994; NAKAGAWA et al., 1997).

In the study of NIKUNEN et al. (2007) on 84 calves with bovine respiratory disease (BRD), trachea bronchial lavage samples were examined for bacteria and the serum samples were tested for antibodies against the virus. In the same study, the calves were clinically diagnosed with diarrhea, high fever and an increase in respiratory rate; WBC value presented no variations in calves with viral and bacterial pneumoenteritis whereas the concentration of SAA proved to be high in pneumonia and pneumoenteritis cases based on Pasteurella (NIKUNEN et al., 2007). Several researchers have reported that SAA is the first acute phase protein increase in calves with respiratory system diseases (ANGEN et al., 2009; ORRO et al., 2011). In our study, the concentration of SAA was determined to be higher in the calves clinically diagnosed with pneumonia, pneumoenteritis and enteritis than in the control group. We consider that the reason for this is inflammation is the same case that in the studies mentioned above.

BURCIAGA-ROBLES et al. (2010) performed experimental BVDV, mannheimia hemaloytica $(\mathrm{mh})$ and BVDV $+\mathrm{mh}$ applications on calves, thus created pneumonia, pneumoenteritis and enteritis in calves. Then, in all groups experimental infection was created, the concentrations of serum TNF- $\alpha$, IL- $1 \beta$ and IL- 6 were found to be higher than in the control group. In our study, the lowest $(\mathrm{P}<0.0001)$ concentrations of serum TNF- $\alpha$, IL- $1 \beta$ and IL- 6 were determined in group $\mathrm{C}$, as well. The highest Serum TNF- $\alpha$ concentration was found in group $P$, the highest serum IL-1 $\beta$ concentration was seen in group PE, and serum IL-6 concentration was the highest in group E. Some researchers indicated that on the $4^{\text {th }}$ day the concentration of serum IL-6 increased in the calves which had experimental bovine respiratory syncytial virus (BRSV) was performed while the concentration of serum IL-6 remained the same in these animals during the reinfection occurring on day $98^{\text {th }}$ (GRELL et al., 2005). In another study on calves, experimental pneumonia and pneuomoenteritis was created and monitored for 14 days resulting in no change in the concentration of serum IL-1 $\beta$ (RISALDE et al., 2011). In our study, proinflammatory cytokines (TNF $\alpha$, IL-1 $\beta$ ve IL-6) were detected to be higher in the calves with clinical pneumonia, pneumoenteritis and enteritis than in the control group. We suggest that the existing inflammation in the studied group is the cause for this.

Regarding the results obtained from the presented study, it has been identified that haematological and biochemical parameters accompanied clinical symptoms of the elevation in serum SAA concentration in calves with pneumonia, pneumoenteritis and enteritis. SAA was detected at very low concentrations in the healthy animals in the control group. In the light of these findings we acknowledge that routine measurements of serum SAA concentration from the moment the calves are diagnosed with pneumonia, enteritis and pneumoenteritis in veterinary medicine until the actual cause is determined (bacteria, virus, parasites, etc.), we also believe that more studies on the clinical use of SAA are needed.

\section{ACKNOWLEDGEMENT}

The research was supported in part by a grant (project number;11.VF.04) from Afyon Kocatepe University. 


\section{BIOETHICS AND BIOSSECURITY COMMITTEE APPROVAL}

We authors of the article entitled "The detection of serum amyloid-A concentration in the calf clinically diagnosed with pneumonia, enteritis and pneumoenteritis" declared, for all due purposes, that the project that gave rise to the present data has not been submitted for evaluation of the Ethics Committee of the "Afyon Kocatepe University", but we are aware of Brazilian content resolutions of the National Council for Control of Animal Experimentation - CONCEA <http://www.mct.gov.br/index.php/ content/view/310553.html $>$ if it involves animals.

Thus, the authors assume full responsibility for the presented data and are available for possible questions, if they would be required by the competent authorities.

\section{REFERENCES}

ALSEMGEEST, S.P.M. et al. Concentrations of SAA (SAA) and haptoglobin $(\mathrm{Hp})$ as parameters of inflammatory diseases in cattle. Veterinary Quarterly, v.16, p.21-23, 1994. Available from: <http:// www.ncbi.nlm.nih.gov/pubmed/8009814>. Accessed: nov. 20, 2012.

ANGEN, Ø. et al. Respiratory disease in calves: Microbiological investigations on trans-tracheally aspirated bronchoalveolar fluid and acute phase protein response. Veterinary Microbiology, v.137, p.165-171, 2009. Available from: <http://www.sciencedirect.com/ science/article/pii/S037811350800610X >. Accessed: May 28, 2009. doi: 10.1016/j.vetmic.2008.12.024.

BRUN-HANSEN, H.C. et al. Hematologic values in calves during the first 6 months of life. Veterinary Clinical Pathology, v.35, n.2, p.182-187, 2006. Available from: <http://onlinelibrary.wiley.com/doi/10.1111/j.1939165X.2006.tb00111.x/abstract>. Accessed: Mar. 5, 2008. doi: 10.1111/j.1939-165X.2006.tb00111.x.

BURCIAGA-ROBLES, L.O. et al. Effects of exposure to calves persistently infected with bovine viral diarrhea virus type $1 \mathrm{~b}$ and subsequent infection with mannheima haemolytica on clinical signs and immune variables: model for bovine respiratory disease via viral and bacterial interaction. Journal Animal Science, v.88, n.6, p.2166-2178, 2010. Available from: <https://www. animalsciencepublications.org/publications/jas/articles/88/6/2166>. Accessed: December 4, 2014. doi: 10.2527/jas.2009-2005.

CECILIANI, F. et al. Acute phase proteins in ruminants. Journal of Proteomics, v.75, p.4207-4231, 2012. Available from: <http:// www.sciencedirect.com/science/article/pii/S1874391912002102>. Accessed: Jul. 19, 2012. doi: 10.1016/j.jprot.2012.04.004.

DONOVAN, G.A. et al. Calf and disease factors affecting growth in female Holstein calves in Florida, USA. Preventive Veterinary Medicine, v.33, p.1-10, 1998.

ECKERSALL, P.D.; BELL, R. Acute phase proteins: Biomarkers of infection and inflammation in veterinary medicine. Veterinary Journal, v.185, p.23-27, 2010. Available from: <http://www. sciencedirect.com/science/article/pii/S1090023310001176>. Accessed: July 2010. doi: 10.1016/j.tvj1.2010.04.009.

GRELL, S.N. et al. Marked induction of IL-6, haptoglobin and IFN gamma following experimental BRSV infection in young calves. Veteterinary Immunology and Immunopathology, v.103, n.3-4, p.235-245, 2005.
GRUYS, E. et al. Diagnostic significance of the major acute phase proteins in veterinary clinical chemistry. A Revue Veterinary Bull, v.64, p.1009-1018, 1994. Available from: <http://www.ncbi. nlm.nih.gov/pmc/articles/PMC1390650/>. Accessed: Oct. 28, 2005. doi: 10.1631/jzus.2005.B1045.

GULLIKSEN, S. et al. Calf mortality in Norwe-gian dairy herds. Journal of Dairy Science, v.92, p.2782-2795, 2009. Available from: <http:/www.sciencedirect.com/science/article/ pii/S0022030209705958>. Accessed: June 2009. doi: 10.3168/ jds.2008-1807.

GÜNEŞ, V. et al. Neonatal buzağilarin solunum sistemi hastalikları.Türkiye klinikleri. Journal of Veterinary Science, v.4, n.1, p.86-94, 2013.

HANZLICEK, G.A. et al. Serial evaluation of physiologic, pathological, and behavioral changes related to disease progression of experimentally induced Mannheimia haemolytica pneumonia in postweaned calves. American Journal of Veterinary Research, v.71, p.359-369, 2010.

HEEGAARD, P.M.H. et al. The acute phase response of haptoglobin and serum amyloid A (SAA) in cattle undergoing experimental infection with bovine respiratory syncytial virus. Veterinary Immunology and Immunopathoogy, v.77, p.151159, 2000. Available from: <http: www.sciencedirect.com/science/ article/pii/S0165242700002269>. Accessed: Nov. 23, 2000. doi: 10.1016/S0165-2427(00)00226-9.

HORADAGODA, A. et al. Purification and quantitative measurement of bovine SAA. Research in Veterinary Science, v. 55, p. $317-325,1993$

MERCK MANUAL. Serum biochemical reference ranges, 2013. Available from: <http:/www.merckmanuals.com/vet/appendixes/ reference guides/serum biochemical reference ranges.html>. Online. Accessed: Nov. 2013.

MURATA, H. et al. Current research on acute phase proteins in veterinary diagnosis: an overview. Veterinary Journal, v.168, p.28-40, 2004. Available from: <http://www.sciencedirect.com/ science/article/pii/S1090023303001199>. Accessed: July 2004. doi: 10.1016/S1090-0233(03)00119-9.

NAKAGAWA, H. et al. Detection of serum haptoglobin by enzyme-linked immunosorbent assay in cows with fatty liver. Research in Veterinary Science, v.62, p.137-141, 1997. Available from: <http://www.sciencedirect.com/science/article/ pii/S0034528897901351>. Accessed: March-April 1997. doi: 10.1016/S0034-5288(97)90135-1.

NIKUNEN, S. et al. Association of bovine respiratory disease with clinical status and acute phase proteins in calves. Comperative Immunology Microbiology Infectious Diseases, v.30, n.3, p.143-151, 2007. Available from: < http://www.sciencedirect.com/ science/article/pii/S0147957106001044?np=y>. Accessed: May 2007. doi: 10.1016/j.cimid.2006.11.004.

ORRO, T. et al. Acute phase protein changes in calves during an outbreak of respiratory disease caused by bovine respiratory syncytial virus. Comperative Immunology Microbiology Infectious Diseases, v.34, p.23-29, 2011. Available from: <http://www.sciencedirect.com/science/ article/pii/S014795710900057>. Accessed: January 2011. doi: 10.1016/j.cimid.2009.10.005. 
PETERSEN, H.H. et al. Application of acute phase proteinmeasurements in veterinary clinical chemistry. Veterinary Research, v.35, p.163-187, 2004. Available from: <http://www. vetres.org/articles/vetres/pdf/2004/02/V4202.pdf>. Accessed: Nov. 18, 2003 doi: 10.1051/vetres:2004002.

PICCIONE, G. et al. Monitoring of physiological and blood parameters during perinatal and neonatal period in calves. Arquivo Brasileiro de Medicina Veterinaria e Zootecnia v.62, n.1, p.1-12, 2010. Available from: <http://www.scielo.br/ pdf/abmvz/v62n1/v62n1a01.pdf>. Accessed: Nov. 6, 2009 doi: 10.1590/S0102-09352010000100001.

RISALDE, M.A. et al. Response of proinflammatory and antiinflammatory cytokines in calves with subclinical bovine viral diarrhea challenged with bovine herpesvirus-1. Veterinary Immunology Immunopathology, v.144, p.135-143, 2011. Available from: $<$ http://www.sciencedirect.com/science/article/pii/ S0165242711002935>. Accessed: Nov. 15, 2011 doi: 10.1016/j. vetimm.2011.07.022.

STANTON, A.L. et al. The effect of respiratory disease and a preventative antibiotic treatmenton growth, survival, age at first calving, and milk production of dairyheifers. Journal of Dairy Science, v.95, p.4950-4960, 2012. Available from: <http://www. sciencedirect.com/science/article/pii/S0022030212005097>. Accessed: Sept. 2012 doi: 10.3168/jds.2011-5067

VAN DONKERSGOED, J. et al. Epidemiological study of enzootic pneumonia in dairy calves in Saskatchewan. Canaian Journal of Veterinary Research, v.57, p.247-254, 1993.

VIRTALA, A.M. et al. The effect of calf-hood diseases on growth of female dairy calves during the first 3 months of life in New York State. Journal of Dairy Science, v.79, p.1040-1049, 1996.

WALTNER-TOEWS, D. et al. Dairy calf manage-ment morbidity and mortality in Ontario Holstein herds. I: the data. Preventive Veterinary Medicine, v.4, p.103-124,1986.

WINDEYER, M.C. et al. Factors associated with morbidity, mortality, and growth of dairy heifer calves up to 3 months of age. Preventive Veterinary Medicine, v.113, p.231-240, 2014 Available from: <http://www.sciencedirect.com/science/article/ pii/S016758771300329>. Accessed: Feb. 12014 doi: 10.1016/j. prevetmed.2013.10.019. 


\section{ERRATUM}

Artigo "Detection of serum amyloid-A concentration in the calf clinically diagnosed with pneumonia, enteritis and pneumoenteritis" publicado no fascículo v46n2 de fevereiro da Ciência Rural páginas 293-299, onde se lia:

“A detecção de amilóide-A concentração sérica na panturrilha com diagnóstico clínico de pneumonia, enterite e pneumoenterites"

leia-se:

"A detecção de amilóide-A concentração sérica em bezerros com diagnóstico clínico de pneumonia, enterite e pneumoenterites"

Para a versão correta, acesse:

http://www.scielo.br/pdf/cr/v46n2/1678-4596-cr-46-02-00293.pdf 